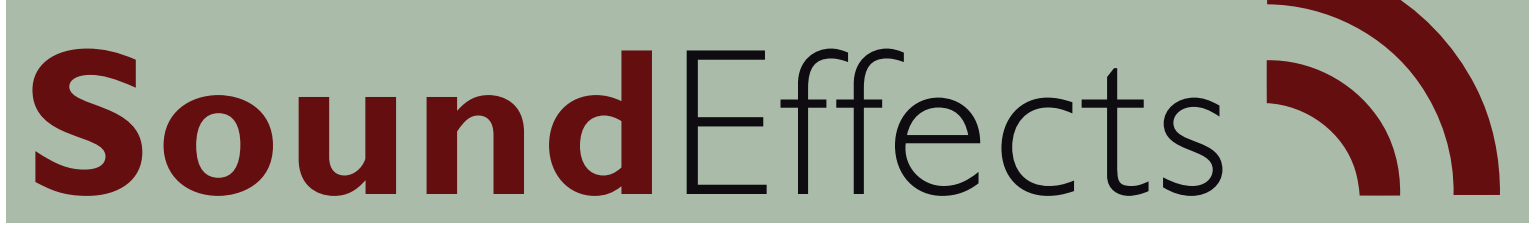

An Interdisciplinary Journal of Sound and Sound Experience

\title{
Philippa Lovatt
}

\section{Carceral soundscapes}

Sonic violence and embodied experience in films about imprisonment

\section{Philippa Lovatt}

Lecturer in Media and Communications

University of Stirling 


\begin{abstract}
Post 9/11 the 'invisibility' of political prisoners as part of the 'war on terror' has had a direct correlation with the concealment of abusive treatment of detainees in the detention camps at Guantánamo Bay and Abu Ghraib. Details of these abuse scandals have indicated that there has been a notable shift away from the optical towards the sonic as a form of punishment and torture, with accounts of detainees being subjected to rock music played for prolonged periods at excruciating volumes (Smith, 2008). Addressing a number of key concerns - sound and phenomenology, sound and the ethics of spectatorship, sound and the experience/intensification of confinement, sound as a (potential) mode of resistance/control - this paper will investigate the use of sound in cinematic depictions of imprisonment including A Man Escaped (Bresson, 1956), Hunger (McQueen, 2008) and Zero Dark Thirty (Bigelow, 2012). The aim is to explore how an auditory perspective might complicate previously held ocularcentric conceptions of power in penal institutions (Foucault, 1977) and to examine how this experience of sound is represented on screen. The essay also considers how sound design can bridge the distance between self and other, and align the spectator emotionally, ethically and politically with a film's characters. The essay thus proposes that an ethical spectatorship may require cinematic auditors to listen more critically, and it claims that a better understanding of the fundamental role that sound and listening play in the articulation and recognition - or indeed, disavowal of the subjectivity of prisoners within these narratives may lead to an increased awareness of the politics of aesthetics of individual films. The essay concludes by suggesting that the field of sound studies creates further opportunities for research that explores these important questions about representation, spectatorship and ethics from a range of disciplinary perspectives.
\end{abstract}

Recently there has been a surge of interest in film studies around questions of ethical spectatorship and its relationship to affect (Downing and Saxton, 2010; Chaudhuri, 2014; Choi and Frey, 2014). In these discussions the notion of sensorial engagement with, and response to, film texts and how this might lead to an awareness of a responsibility to others is crucial. As Vivian Sobchack argues, "[c]entral to any understanding of the connection between ethics and aesthetics [is] the question of "the limit between the body and the world"' (Sobchack, 2004, p. 286). The sonic has an intimate connection to our bodies: A sound wave only becomes a sound when it reaches and vibrates the bones of the inner ear, and this may explain why sound design in film and television has the power to move us both physically and emotionally. However, the act of listening is also an intrinsically social process that bridges the distance between self and other. As Brandon LaBelle suggests, "through listening an individual is extended beyond the boundaries of singularity [...] toward a broader space necessarily multiple' (LaBelle, 2006, p. 245). Similarly, Jean-Luc 
Nancy argues that 'the sonorous [is] tendentially methexic (that is, having to do with participation, sharing, or contagion)' (Nancy, 2007, p. 10).

In Noise: The Political Economy of Music Jacques Attali contends that the sonic has the ability to make material the abstract notion of power, and to both map out and 'occupy' territory. For him, it plays a fundamental role in the organisation of social structures, as he argues, 'any organization of sounds is [...] a tool for the creation or consolidation of a community, of a totality' (Attali, 1985, p. 6). The ability of sound to map physical and social space in this way has long been a subject of study for anthropologists and ethnomusicologists; however, in this essay I am interested in exploring how these ideas about sound, power, control and space can be mapped onto the microcosm of the prison environment as it has been represented on screen. This essay will examine how in the prison film the sonic can communicate both the experience and intensification of confinement, while at the same time expressing a (potential) mode of resistance or control.

If, as Colin McGinn asserts, 'reading novels, watching plays and films [...] is the primary way in which [we] acquire ethical attitudes' (McGinn cited in Downing and Saxton, 2010, p. 1), what role, this essay asks, does listening play in this process? Point-of-audition grants us access to the subjective experience of a character and has the potential to align us with them emotionally and politically, producing a sense of intersubjectivity that Jane Stadler describes as 'an overlapping or sharing of subjectivity such that a person gains knowledge of another subject's mental, experiential, or emotional state' (Stadler, 2014, p. 38). This essay explores the relationship between sound and intersubjectivity, how certain recording methods and uses of rhythm in the diegetic soundscapes might create a feeling of intimacy and closeness through their appeal to the spectator's embodied self, but which might also bring about feelings of fear and/or disgust through enforced aural proximity. The former of these two ideas opens up possible areas for future interdisciplinary research: How might feelings of empathy towards characters in prison dramas and documentaries encourage better understanding of former prisoners upon their release into society? Furthermore, how might empathy and understanding allow ex-offenders to reimagine a more positive identity for themselves, one that enables them to desist from reoffending?

\section{Punishing sounds}

Post 9/11 the 'invisibility' of political prisoners as part of the 'war on terror' has had a direct correlation with the concealment of abusive treatment of detainees in the detention camps at Guantánamo Bay and Abu Ghraib. Details of these abuse scandals have indicated that there has been a notable shift away from the optical towards the sonic as a form of punishment and torture, with accounts of detain- 
ees being subjected to rock music played for prolonged periods at excruciating volumes. As Ian E. Hill describes, 'sound reproduction technologies' have been used 'to blast prisoners with a continuous noise at peak loudness in order to coerce cooperation' (Hill, 2012, p. 217; see also Goodman, 2010; Johnson and Cloonan, 2008). The use of sound as an instrument of torture and control is not new of course: In Nazi concentration camps prisoners were forced 'to mock their grim reality by singing about cheerful, carefree themes' (Gilbert, 2005, p. 117), and as Carolyn Birdsall has described, the National Socialists habitually used music and sound to exert control over urban space in Nazi Germany, as did the Communist Party during the Cultural Revolution in China (Birdsall, 2012; Baranovitch, 2003). More recently, sonic violence has manifested itself as the inverse of this process, where noise cancellation technologies have been used to facilitate sensory deprivation as another form of punishment.

Hillel Schwartz' Making Noise: From Babel to the Big Bang and Beyond describes how in the late 1700s prisons were extremely noisy places. However, from the turn of the century, he notes, this began to change: Prisons were part hospitals, part insane asylums, part poorhouses and began around this time to be thought of as 'correction houses', making them orderly and relatively quiet. The architecture of the prisons also began to change at this time with the development of penitentiaries. These were specifically designed to silence the prisoners: Soundproofing enabled solitude, which was considered vital for the 'correction' of the soul (Schwartz, 2011, pp. 182183). Schwartz explains that when 'reformatories' were introduced in America in the twentieth century, and the number of inmates dramatically increased, silence could no longer be maintained and yet remained the first rule that was posted onto the wall of each inmate's cell, meaning that silence continued to be 'a potent signifier of what it meant to be unfree' (Schwartz, 2011, p. 202).

While the role of the sonic in producing submissive subjects in penal institutions has begun to be investigated in some recent practice-based research in the fields of acoustic ecology and sound art, such as Sahar Kubba's installation Unsignal (2013), Sonia Leber and David Chesworth's Separate Prison (2008, Port Arthur, Tasmania) and Trevor Paglen's reflective essay Recording Carceral Landscapes (2005), there remains a great deal to be explored about this largely neglected, but crucially important area of study. This essay expands on the existing literature concerning the relationship between the prison film and penal reform, and in particular, the argument put forward by David Wilson and Sean O'Sullivan that: 'Society needs to be encouraged to see prisoners as people who potentially have rights and aspirations before it can even begin to engage in a debate about the acceptability of penal regimes' (Wilson and O'Sullivan, 2005, p. 486; see also Nellis and Hale, 1982). To do this it claims that an auditory perspective can complicate, and challenge, previously held (ocularcentric) conceptions of power in penal institutions, drawing on and contributing to 
existing work on sound and space and sound and power in the field of sound studies (Corbin, 1999; Feld, 1996; LaBelle, 2010) and theories of embodied spectatorship in film studies (Barker, 2009; Marks, 2000; Quinlivan, 2014; Sobchack, 1992).

\section{Auditory perspective}

We know from the way music can make us move that sound's material, physical properties can have a direct impact on our bodies and our state of mind at the same time (listening to music and dancing, for example, usually produces a sense of well-being). However, sonic torture, in all of its varying manifestations, has been proven to cause psychological trauma and often physical pain that significantly weakens the body and the individual's mental state, producing in the sufferer what Foucault referred to as the 'docile body' responsive to the manipulation and control of the state (Foucault, 1977). While on the one hand, prison soundscapes in film communicate that sense of control over space - often using 'iconic' prison sounds that have now become clichés of the genre, such as the turn of the key in the lock or the slamming of a cell door (synonymous with slang for prisons: the 'clink' or the 'slammer') - they can also convey individual or collective resistance to that control. ${ }^{1}$ Following Emily Thompson's assertion that 'a soundscape is simultaneously a physical environment and a way of perceiving that environment', I contend that sound design can provide insights into how characters perceive the world around them, as subtle changes in auditory perspective highlight the subjective and phenomenological experience of the environment (Thompson, 2004, p. 1). Sound design also plays a crucial role in shaping the spectator's responses to what is happening in a particular moment on screen. Using techniques such as aural zoom, for example, can bring us perceptually closer to something, whether a whisper or a floorboard creaking. In this way, as noted earlier, the auditory aligns us with the perspective of particular characters, producing a sensory connection that can (although importantly does not always) encourage a sense of intimacy and sometimes empathy with their situation.

An important prison film in which aural perspective is used to align spectators with certain characters is Robert Bresson's A Man Escaped (1956). The film tells the story of Fontaine, a French WWII resistance fighter, who is imprisoned and sentenced to death, but manages to escape and lives to tell his story. Narrated through first-person voice-over (as Fontaine describes his prison experience and how he carried out his escape), every detail in the film is rendered from his perspective, particularly (given his confinement) his auditory perspective. Fontaine's sense of hearing allows him to understand his spatial surroundings beyond the cell. Through off-screen sound he becomes familiar with the daily routines of the guards, enabling him to gain a sense of time, and he can communicate with fellow 
inmates by tapping on the walls between the cells. He is even able to understand the rhythms of the world beyond the prison to some extent through the sounds of the immediate environment that float through his small, barred window: the regular whistle of the nearby train as it rattles past and the habitual comings and goings in the street below. It is only because of this aural understanding that he is able to plan and eventually make his escape. The sonic therefore has a crucial narrative role in the film, as John Belton elaborates:

\section{Sound functions here to direct our attention toward objects and to create suspense, but it also reduces the entire scene to a drama played out between one sound and another, between metal on concrete and footsteps. Sounds become extensions of the characters - of Fontaine and the guard. This is a kind of intensification of the status of these sounds; the sounds are there not merely to suggest time or place or to create atmosphere but to bear the weight of the drama. (Belton, 2008, p. 27)}

The sound design, which importantly uses only diegetic sound (with the exception of refrains of Mozart's Mass in C Minor at certain points), gives the film its rhythm and pace, while at the same time creating dramatic tension and empathy with Fontaine's struggle. In several scenes, for example, we see and hear him scraping at the wood on the cell door with a spoon that he has concealed from the guards. The point-of-audition here is from his perspective: He knows that he might be discovered at any moment, and so the scratching itself seems to stand out against the other diegetic sounds. For the listener, it seems amplified at this moment, as if we too have the heightened senses of an anxious state of mind.

According to Vivian Sobchack, 'Cinema [...] transposes, without completely transforming, those modes of being alive and consciously embodied in the world that count for each of us as direct experience' (Sobchack, 1992, p. 4). As Thomas Elsaesser and Malte Hagener have described, however, this is not just achieved through the visual aspects of cinema, but also through its sound design: 'The spectator [...] exists as a bodily being, enmeshed acoustically, senso-motorically, somatically and affectively in the film's visual texture and soundscape' (Elsaesser and Hagener, 2010, p. 10). We come to understand the interior space of the prison in A Man Escaped in this way, as the haptic quality of particular objects (the water in the washroom that conceals the prisoners' talk, the squeaky screws that Fontaine removes from his cell door, the brittle crunch of the glass he breaks beneath his blanket) adds texture to the film's mise-en-scène, which encourages an affective, potentially empathetic engagement with the scene by placing us imaginatively and phenomenologically within the prison space through our sense of hearing.

Power in A Man Escaped is treated abstractly: We hear the acousmatic voices of the SS guards speaking in German (untranslated by the subtitles) and we feel their presence as we hear the resonance of their keys as they rattle them along the echoing stairwell and the corridors outside the cells. Frequently we are denied access to 
the visible source of the sound, meaning that it is our sense of hearing that makes us very much aware of the imminent and constant threat of violence. The physical beatings that Fontaine is subjected to by the guards are withheld from us in the image, although we do see the aftermath hereof when his bloodied, unconscious body is laid down on the concrete floor of his cell. Instead, as Belton suggests above, it is often the sound rather than the image that 'bear[s] the weight of the drama', as oppression itself seems to be embodied, in quite an abstract sense, by particular acoustic reverberations within the space of the prison. By contrast, the purposeful scratching sounds that Fontaine makes against his door or the soft tapping of Morse code on the wall suggest the rearticulation of the subject through the production of sound: These are sonic manifestations of resistance to the psychological violence imposed on the prisoner by enforced silence.

Set in the Maze Prison just outside of Belfast, Steve McQueen's Hunger (2008) tells the story of the IRA blanket protest and hunger strikes that took place between 1979 and 1981. Like Bresson's film, the story is told from the perspective of a political prisoner (Bobby Sands), but only gestures towards the wider political and historical context of the film: the 'troubles' in Northern Ireland. The very beginning of the film foregrounds the significance of sound, and specifically noise, as a mode of politicised struggle. Set against a black screen as the opening credits roll, we hear (before we see) the insistent rhythm of women bashing dustbin lids onto the streets of the city. Distant at first, and disorientating because the source of the noise is not immediately clear, it quickly builds to a crescendo as the audience is presented with what Caoimhín Mac Giolla Léith refers to as a 'sound that registers in the gut before it reaches the ear and is subsequently parsed by the brain: sound in its phenomenal rather than its systemic, which is to say linguistic, aspect' (Léith, 2008).

With the exception of a lengthy discussion between Sands and a priest (Father Dominic Moran) in the middle of the film, exposition is limited. Dialogue is often simply just another kind of noise, as Léith comments:

\section{[M]ore often than not [in the film], speech is subordinated to sound. Brute noise repeatedly overcomes articulated language, from the film's opening scene of Repub- lican women loudly clattering bin lids in protest and lamentation, through scenes of prison brutality in which prisoners' cries are muted by the ritualistic banging of truncheons on riot shields, to the closing scenes in the prison hospital when a muf- fled soundtrack indicates Sands' loss of hearing owing to his body's privations. (Léith, 2008)}

Instead of through language then, Hunger communicates the human experience of incarceration through the immersive quality of the sound design (by Paul Davies) and the non-linear narrative. Like A Man Escaped the sound design is sparse, concentrating our auditory attention on the materiality of the space in which the story takes place, encouraging audiences' understanding of the 'geography of the room' 
not through sight, but 'through another sensory device': hearing (McQueen in Reinhert, 2001). McQueen explains, 'A sound can give you the dimensions of a room. It can give you smell, it can give you tension. In some ways sound can travel itself into other areas of our senses, other areas of our psyche that unfortunately cannot be just viewed' (McQueen in Reinhert, 2009).

Early on in the narrative the film documents that the Thatcher government refused to give IRA members the status of political prisoners. We hear the uncanny, acousmatic voice of Margaret Thatcher through a radio as she makes a speech to parliament:

Faced now with the failure of their discredited cause the men of violence have chosen in recent months to play what may well be their last card. They've turned their violence against themselves through the prison hunger strike to death. They seek to work on the most basic of human emotions: pity, as a means of creating tension and stoking the fires of bitterness and hatred.

In contrast to the embodied physicality of the rest of the mise-en-scène, Thatcher's voice is perceived as distant, literally in terms of geographical location (a broadcast connotes 'elsewhere' in time and space) and emotion. Appropriately, McQueen describes her voice as a 'vapour [...] the lock and key of the prison' (McQueen in Reinhert, 2009).

As a result of the British government's withdrawal of the inmates' rights as political prisoners, the men have no power whatsoever. Consequently, the human body itself becomes the site of protest. Simply put, the men have nothing else: Excrement is caked and smeared onto cell walls, urine floods out under cell doors, and saliva is spat in the faces of the guards, the only means through which the prisoners can put up any kind of resistance. Having had their civilian clothes removed (but refusing to wear prison garb), the prisoners are naked, they refuse to wash or cut their hair, and following the hunger strike, the final act of resistance is the slow, agonising death of Bobby Sands. The guards punish these protests by carrying out humiliating beatings, scenes that are depicted with acute attention to sensory detail. As Bacal observes:

Essentially concerned with the extreme states of bodies, whether in their vulnerability or in their potential as tools of political resistance, Hunger dwells upon the lived and felt experiences of bodies within spaces where their social and political rights are reduced to almost nothing. This precarious relation between the political body and the imprisoned body (respectively the material embodiment of a political subject and an object of power by which political subjectivity can be violated) stands at the core of the film and the sensory ambivalence McQueen evokes. (Bacal, 2013, p. 12)

With a background in video and installation work, McQueen has described how with Hunger he wanted audiences to be physically aware of themselves while watch- 
ing the film, and to imaginatively place themselves within the space of the prison, in order for them to be able 'to feel the weight in an hour and a half of that time in history' (McQueen in Reinhert, 2009). ${ }^{2}$ The film is a visceral and often distressing experience for the viewer because of the degree of violence depicted. Bodily sounds such as Sands' strained breath as he slowly starves to death, the wet squelch of a finger inserted roughly into the mouth and the rectum of a prisoner during a brutal internal examination, or the dull thuds of the guards' truncheons on the prisoners' backs are foregrounded on the soundtrack to such an extent that it is impossible not to imagine, not to feel, that this violence is somehow occurring in real time and space before us. The foregrounding of a corporeal subjectivity invites a bodily response from the spectator. But as well as horror and revulsion, certain sounds create a space for contemplation and reflection that may also lead to a more ethical engagement with the film. As Davina Quinlivan describes in The Place of Breath in Cinema, because of the way that breathing 'destabilise[s] the boundaries of the body', the sound of breathing in film can 'attune' the viewer to the body on screen, particularly at moments intended to 'evoke suffering or intense emotion' (Quinlivan, 2012, p. 105, 163). In Hunger the sound of Sands' breath at the point at which he begins to lose consciousness merges with our own, blurring the boundaries between interior and exterior, self and other, in a way that also bridges the distance between the cinematic and the real. We may try to look away, but the sounds stay with us, their vibrations invading our own embodied sense of self. ${ }^{3}$

\section{The 'charge of the real'}

Recent writing on film sound and violence by Lisa Coulthard, William Whittington and Ben Winters, amongst others, has tended to focus on the visceral sound design of the horror genre and related groups of films such as body horror, the slasher movie, torture porn and 'New Extremist cinema', in which the amplification of hyperreal sounds to emphasise the vulnerability of the body under attack or low-frequency drones meant to bring about a feeling of unease in the spectator are common techniques (Coulthard, 2013; Whittington, 2014; Winters, 2008). Collectively, these films can be thought of as 'body genres', where, Linda Williams explains, 'the body of the spectator is caught up in an almost involuntary mimicry of the emotion or sensation of the body on the screen' (Williams, 1991, p. 4). In the horror genre in particular it is generally accepted that we have to identify with either the victim or the perpetrator in order for the film to 'work', and indeed this process is often considered one of its pleasures. Films that deal with political violence have a very different register, however, to the groups of films mentioned above, which do not necessarily have a specific political or ideological agenda and are designed primarily as entertainment (of some kind). What happens then to these processes of identification when we see 
and hear extreme violence or torture on screen perpetrated by the state, and in what ways can sound position the spectator ethically?

The use of sound (in the form of white noise and music of all genres) as a tool of 'enhanced interrogation' first came to the public's attention during the Iraq War. Played at excruciating volume while the detainee is subjected to other forms of sensory deprivation (for example, is blindfolded and placed in a stress position), the sufferer loses all sense of his or her subjectivity. Former Guantánamo Bay detainees interviewed by musicologist Suzanne G. Cusick have described how during their containment music would be played through speakers throughout the day and night along the concrete corridors, often shifting suddenly between musical styles in order to underscore the unpredictability of their situation and their lack of control over their environment. Music in this context is used as a way of 'occupying' prisoners' thoughts; it is intended to erase the enemy's sense of self by ensuring that they can no longer hear themselves think. As Cusick explains, it is intended to:

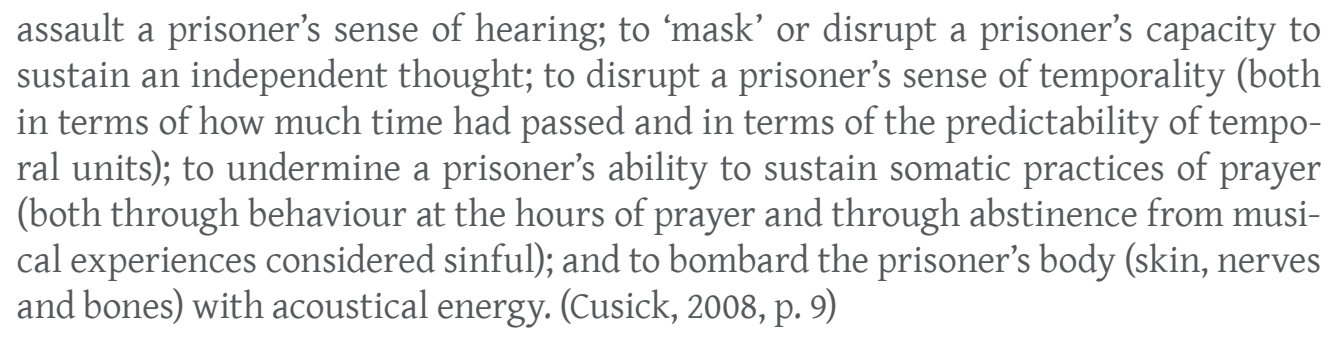

The lack of autonomy over the acoustic environment that Cusick describes here equates to the disavowal of the subject within the space of the prison, which occurs in both of the films discussed so far. Denied the freedom to retreat into private space, prisoners are forced into 'a dystopic public' from which it is impossible to escape (Cusick, 2008, p. 9).

Elaine Scarry has described how torture creates for the perpetrators and the regime that they represent the 'fiction of power' by disavowing the agency of the prisoner, turning their suffering into a 'spectacle'. Because, she contends, '[t]he physical pain is so incontestably real [...] it seems to confer its quality of "incontestable reality" on that power that has brought it into being. And yet, she continues, "[i]t is precisely because the reality of that power is so highly contestable, the regime is so unstable, that torture is being used' (Scarry, 1985, p. 27). There is a great deal at stake therefore for films like Kathryn Bigelow's Zero Dark Thirty (2012), which depict such practices in terms of how audiences perceive and experience the horror that is at the core of the film. Much of the criticism around this particular film relates to the potentially dangerous 'real-life' impact that it could have on debates around the use of torture in detention centres. A classified memo that was leaked in May 2013 reportedly revealed that the CIA put pressure on the screenwriter Mark Boal to change or remove the scenes that depicted torture, because, it was claimed, 
they were an inaccurate representation of the real events that took place in the run-up to the killing of Osama bin Laden. Originally, the script had included the CIA agent Maya taking an active role in the water-boarding of a detainee, but this was changed to show her observing the torture rather than carrying it out herself. Another scene showing the use of dogs to intimidate detainees was also taken out, reportedly again because the CIA claimed that this was not an accurate portrayal of the practices of 'enhanced interrogation' (Child, 2013).

The film, which tells the story of the CIA's hunt and eventual assassination of bin Laden in Pakistan in 2011, uses point-of-audition to facilitate audience identification with Maya. Rick Altman has theorised point-of-audition (relating to aural perspective) as having the 'effect of luring the listener into the diegesis not at the point of enunciation of the sound, but at the point of its audition. Point-of-audition sound thus relates us to the narrative not as external auditors, identified with the camera and its position [...] nor as participant in the dialogue [...] but as internal auditor' (Altman, 1992, p. 51). In this way, audiences are aligned with Maya's perspective (who essentially hears on our behalf), and because of this illusion of intimacy, we are invited to place our trust in her and allow her to lead us through the narrative. It is surely for this reason that Maya could not be seen to be actively carrying out acts of torture: We, the audience, would not want to bear the responsibility for this act by implication.

At the beginning of Zero Dark Thirty, the words 'Based on Firsthand Accounts of Actual Events' momentarily flash up on the screen before being supplanted by a date: 'September 11, 2001'. Alongside this, recordings of genuine emergency calls made by victims during the attack on the World Trade Center in New York are played on the soundtrack against a black screen. These are the voices of the dead, recorded in their last few moments of life, and replayed to us at the opening of a Hollywood film. These ghostly, acousmatic voices are clearly intended to reposition the spectator spatially, temporally and emotionally to that day in 2001 in order to justify any uncomfortable 'truths' that might unfold during the next two and a half hours. Soon after hearing these voices, a detainee named Ammar is shown being tortured. As Steve Coll describes, when we first see him, he is tied at the wrists with rope, he has been strung up and is being subjected to loud rock music. His face is swollen, eyes almost closing; he is waterboarded, deprived of sleep, forced into a small box and sexually humiliated (Coll, 2013). The sustained use of point-ofaudition throughout the film to align the spectator with Maya leaves little room for moral doubt; it serves to disavow the subjectivity of the prisoner and in doing so evades the problematic ethical questions that surround the film.

As with A Man Escaped and Hunger, there are obvious ethical issues concerning this kind of spectatorial positioning. While the sound design facilitates a perceived 'closeness' between auditor (within the film) and spectator, in the case of Zero Dark 
Thirty, there already appears to have been an assumption on the part of the sound designer that audiences would automatically share the perspective of the American characters in the film. Sound designer Paul Ottosson concedes that we are "horrified' by what we witness in this scene and yet goes on to rationalise the use of 'enhanced interrogation techniques' because of what he and the American characters in the film consider to be the 'greater good'. As he explains:

I try to convey things from the person with the strongest point of view in the scene. And this is the first time that Maya witnesses the torture. She's disturbed by what she sees and so are we. But then she becomes so obsessed with the capture of bin Laden and even participates in the interrogation to obtain her goal. At that moment, I don't play these sounds anymore [describing the distorted, ethereal sounds of the Erhu] because, like us, she understands why we have to do this and it's not as appalling. I play up some of the outside sounds to show that she's in control and driving forward. (Ottosson, 2013; emphasis added)

The use of cinematic sound to emotionally manipulate an audience is nothing new. As Claudia Gorbman and many others have described in relation to the film score, this is one of the many pleasures of going to the cinema (Gorbman, 1987). And yet, something much more ethically problematic occurs when those involved in the filmmaking process draw together the fictional with the real, as is the case with each of the films discussed here. The blurring of the boundary between fact and fiction, between archived recording and 're-enactment', produces what Sobchack refers to as the 'charge of the real':

\begin{abstract}
At its most potent, then, the charge of the real that moves us from fictional into documentary consciousness is always [...] an ethical charge: one that calls forth not only response but also responsibility - not only aesthetic valuation but also ethical judgement. It engages our awareness not only of the existential consequences of representation but also of our own ethical implication in representation. It remands us reflexively to ourselves as embodied, culturally knowledgeable, and socially invested viewers. Thus, in those moments in which the fictional space becomes charged with the real, the viewer is also so charged. The charge of the real comprehends both screen and viewer, restructuring their parallel worlds not only as coextensive but also as ethically implicated in the other. (Sobchack, 2004, p. 284)
\end{abstract}

The films that have been the subject of this essay: A Man Escaped, Hunger and Zero Dark Thirty have had in common their relationship to the real. Each narrativises an aspect of political history: the French resistance movement during WWII, the Republican hunger strikes during the 'Troubles' in Northern Ireland and, lastly, the 'war on terror' that followed the attack on the Twin Towers in New York in 2001. Following Sobchack, each of these stories contain within them the 'charge of the real' that requires us to recognise the 'consequences of representation' and 'our own ethical implication' in those representations. 
This investigation into the auditory dimension of films about incarceration and punishment has suggested ways in which an ethical spectatorship may require cinematic auditors to listen more critically. Furthermore, it has proposed that a better understanding of the relationship between sound and power (both on screen and in lived space), and the fundamental role that sound and listening play in the articulation and recognition of the subject, may lead to an increased awareness of the politics of aesthetics of individual films. It has demonstrated that the soundscapes of Bresson's and McQueen's films bring us perceptually closer to Fontaine and Sands, respectively, bridging the distance between self and other, aligning the spectator with the characters emotionally, ethically and politically. Importantly, in these films the phenomenology of sound - the intimacy of the sounding body and the materiality of the space that confines it - foregrounds the personhood of both of these characters. Embedded within the very fabric of the films then is a commitment to human dignity and justice. By contrast, this study has argued, the use of loud rock music in Bigelow's film during the opening scene of torture, and its juxtaposition against the audio recordings of the attack on the World Trade Center, serves to disavow the subjectivity of the prisoner and justify the cruelty that we witness: an 'aesthetic choice', to echo Shohini Chaudhuri, that has much wider ideological implications (2014, p. 19).

In her essay 'Cinema's Compassionate Gaze' Jane Stadler contends that cinema 'can play [a role] in engendering empathy and potentially breaking down the fear, prejudice, or misunderstanding that may surround marginalised groups' (Stadler, 2014, p. 32). While my study has obvious limitations in that I have not interviewed prisoners or audiences about their experiences of the films, it is my hope that this work could inspire further interdisciplinary investigation addressing the questions set out at the beginning of the essay: How might empathy lead to better understanding of former prisoners upon their release into society, and how might this also allow ex-offenders to reimagine a more positive identity for themselves, one that enables them to desist from reoffending? Furthermore, while this essay has begun to suggest ways in which sound design in film can communicate the experience of incarceration and punishment, there are a number of questions that deserve further consideration. For example, the experience of silence and sense deprivation is an important aspect of the process of disempowering prisoners, particularly through solitary confinement, but how can film or other art forms express this very insular, solitary sensory experience? Sound studies provides a unique opportunity to bring together the arts and the sciences in ways that could be useful for both. Bringing into dialogue sound and film scholars as well as practitioners and criminologists could lead to a better understanding of the role of empathy in film spectatorship and the impact that this could have for social justice. 
I would like to extend my sincere gratitude to Dr Sarah Armstrong (Scottish Centre for Criminal Justice Research, University of Glasgow), Professor Mike Nellis (Emeritus Professor in Criminal Justice, University of Strathclyde) and Professor Karen Lury (Professor of Film and Television Studies, University of Glasgow) for their considerable help with the preliminary research for this essay and comments on an earlier draft.

\section{References}

Albrechtsen, Peter. (2011). Paul Davies Special: Sound Design of Hunger - Exclusive Interview. Designing Sound website. September 28, 2011. http://designingsound.org/2011/09/paul-daviesspecial-sound-design-of-hunger-exclusive-interview/. Accessed on October 3, 2013.

Altman, Rick (ed.). (1992). Sound Theory, Sound Practice. London and New York: Routledge.

Attali, Jacques. (1985 [1977]). Noise: The Political Economy of Music. Translated by Brian Massumi. Manchester: University of Minnesota.

Bacal, Edward. (2013). Sharon Lockhart and Steve McQueen: Inside the Frame of Structural Film. Cineaction, 91, 5-13.

Baranovitch, Nimrod. (2003). China's New Voices: Popular Music, Ethnicity, Gender, and Politics, 1978-1997. Berkeley and Los Angeles: University of California Press.

Barker, Jennifer M. (2009). The Tactile Eye: Touch and the Cinematic Experience. Berkeley and Los Angeles: University of California Press.

Belton, John. (2008). The Phenomenology of Film Sound: Robert Bresson's A Man Escaped. In: Jay Beck and Tony Grajeda (eds.), Lowering the Boom: Critical Studies in Film Sound (pp. 23-35). Urbana: University of Illinois Press.

Benshoff, Harry (ed.). (2014) A Companion to the Horror Film. Chichester: John Wiley and Sons.

Birdsall, Carolyn. (2012). Nazi Soundscapes: Sound Technology and Urban Space in Germany, 1933-1945. Amsterdam: Amsterdam University Press.

Brooks, Jodi. 2001. The Sound of Knocking: Jacques Becker's Le Trou (1960). Screening the Past, 12. http://tlweb.latrobe.edu.au/humanities/screeningthepast/firstrelease/fr0301/jbfr12a.htm. Accessed on September 20, 2013.

Bull, Michael and Back, Les (eds.). (2003). The Auditory Culture Reader Oxford: Berg.

Chaudhuri, Shohini. (2014). Cinema of the Dark Side: Atrocity and the Ethics of Film Spectatorship. Edinburgh: Edinburgh University Press.

Child, Ben. (2013). CIA Requested Zero Dark Thirty Rewrites, memo reveals, The Guardian. May 7 , 2013. http://www.theguardian.com/film/2013/may/07/zero-dark-thirty-cia-memo. Accessed on October 10, 2013.

Choi, Jinhee and Frey, Mattias (eds.). (2014). Cine-Ethics: Ethical Dimensions of Film Theory, Practice and Spectatorship. New York and Abingdon, Oxon: Routledge.

Coll, Steve (2013). 'Disturbing' \& 'Misleading': Zero Dark Thirty. The New York Review of Books. February 7, 2013. http://www.nybooks.com/articles/2013/02/07/disturbing-misleading-zero-darkthirty/. Accessed on October 10, 2013.

Corbin, Alain. (1999). Village Bells, Sound and Meaning in the Nineteenth Century French Countryside. New York: Columbia University Press.

Coulthard, Lisa. (2013). Dirty Sounds: Haptic Noise in New Extremism. In: Carol Vernallis, Amy Herzog and John Richardson (eds.), The Oxford Handbook of Sound and Image in Digital Media (pp. 115-126). New York: Oxford University Press. 
Cusick, Suzanne G. (2008). Musicology, Torture, Repair. Radical Musicology, 3. http://www.radicalmusicology.org.uk: 24 pars. Accessed on October 4, 2013.

Davies, Paul. (2012). Aural Imagination. Paul Davies talks about Kevin...and Ratcatcher, Hunger, Love is the Devil, The American, Jonny Greenwood and Robert Bresson. The New Soundtrack, 2(2), 83-96. September.

Desowitz, Bill. (2012). Immersed in Movies: Sound Designer Paul Ottosson Talks Zero Dark Thirty (2012). http://blogs.indiewire.com/thompsononhollywood/immersed-in-movies-sounddesigner-paul-ottosson-talks-zero-dark-thirty. Accessed on October 5, 2013.

Downing, Lisa and Saxton, Libby. (2010). Film and Ethics: Foreclosed Encounters. Abingdon, Oxon: Routledge.

Elsaesser, Thomas and Hagener, Malte. (2010). Film Theory: An Introduction Through the Senses. Abingdon, Oxon and New York: Routledge.

Feld, Steven. (1996). Waterfalls of Song: An Acoustemology of Place Resounding in Bosavi, Papua New Guinea. In: Steven Feld and Keith Basso (eds.), Senses of Place (pp. 91-135). Santa Fe, N.Mex.: SAR Press.

Foucault, Michel. (1977). Discipline and Punish: The Birth of the Prison. New York: Pantheon.

Gilbert, Shirli. (2005). Music in the Holocaust: Confronting Life in the Nazi Ghettos and Camps. New York and Oxford: Oxford University Press.

Goodman, Steve. (2010). Sonic Warfare: Sound, Affect and the Ecology of Fear. Cambridge: MIT Press.

Hill, Ian E.J. 2012. Not Quite Bleeding from the Ears: Amplifying Sonic Torture. In: Western Journal of Communication, 76(3), 217-235. May-June.

Johnson, Bruce and Cloonan, Martin. (2008). The Dark Side of the Tune: Popular Music and Violence. Aldershot, Hampshire: Ashgate.

LaBelle, Brandon. (2006). Background Noise: Perspectives on Sound Art. New York and London: Continuum.

LaBelle, Brandon. (2010). Acoustic Territories: Sound Culture and Everyday Life. New York and London: Continuum.

Léith, Caoimhín Mac Giolla. 2008. Flesh Becomes Words. Frieze, 117. September.

Marks, Laura U. (2000). The Skin of the Film: Intercultural Cinema, Embodiment, and the Senses. Durham and London: Duke University Press.

Nancy, Jean-Luc. (2007). Listening. New York: Fordham University Press.

Nellis, Mike and Christopher Hale (1982). The Prison Film. London: Radical Alternatives to Prison.

Nussbaum, Martha C. (2013). Political Emotions: Why Love Matters for Justice. Cambridge, MA: Harvard University Press.

Paglen, Trevor. (2006). Recording Carceral Landscapes. Leonardo Music Journal, 16, 56-57.

Quinlivan, Davina. (2014). The Place of Breath in Cinema. Edinburgh: Edinburgh University Press.

Reinhert, Jeff. (2009). Hunger Pains: An Interview with Steve McQueen. Reverse Shot. March. http:// www.reverseshot.com/interviews/entry/416/steve-mcqueen. Accessed on October 3, 2013.

Rolinson, Dave. (2005). Alan Clarke. Manchester: Manchester University Press.

Rolinson, David. (2014). The Stripped-Down Studio Space: Play for Today: Psy-Warriors (BBC, 12/5/81) and Centre Play: The Saliva Milkshake (BBC, 6/1/75). Spaces of Television. February 24.

http://blogs.reading.ac.uk/spaces-of-television/2014/02/24/the-stripped-down-studio-spaceplay-for-today-psy-warriors-bbc-12581-centre-play-the-saliva-milkshake-bbc-6175/ Accessed February 6, 2015.

Scarry, Elaine. (1985). The Body in Pain: The Making and Unmaking of the World. New York: Oxford University Press.

Schwartz, Hillel. (2011). Making Noise: From Babel to the Big Bang and Beyond. New York: Zone Books. Smith, Philip. (2008) Punishment and Culture. Chicago and London: University of Chicago Press.

Sobchack, Vivian. (1992). The Address of the Eye: A Phenomenology of Film Experience. Princeton, New Jersey: Princeton University Press. 
Sobchack, Vivian. (2004). Carnal Thoughts: Embodiment and Moving Image Culture. Berkeley, Los Angeles and London: University of California Press.

Stadler, Jane. (2014). Cinema's Compassionate Gaze: Empathy, Affect, and Aesthetics in The Diving Bell and the Butterfly. In: Jinhee Choi and Mattias Frey (eds.), Cine-Ethics: Ethical Dimensions of Film Theory, Practice and Spectatorship (pp. 27-42). New York and Abingdon, Oxon: Routledge.

Thompson, Emily. (2004). The Soundscape of Modernity: Architectural Acoustics and the Culture of Listening in America, 1900-1933. Cambridge: MIT Press.

Williams, Linda. (1991). Film Bodies: Gender, Genre, and Excess. Film Quarterly, 44(4), 2-13. Summer.

Winters, Ben. (2008). Corporeality, Musical Heartbeats, and Cinematic Emotion. Music, Sound, and the Moving Image, 2(1), 3-26. Spring.

Whittington, William. (2014). Horror Sound Design. In: Harry Benshoff (ed.), A Companion to the Horror Film (pp. 168-185). Chichester: John Wiley and Sons.

Wilson, David and Sean O'Sullivan. (2005). Re-theorizing the penal reform functions of the prison film: Revelation, humanization, empathy and benchmarking. Theoretical Criminology. 9(4): 471491. November.

\section{Notes}

1 This 'resistance' is often discussed in relation to the use of music in prison narratives - see, for example, Martha Nussbaum's analysis of 'The Marriage of Figaro' in The Shawshank Redemption (Darabont, 1994) in Political Emotions: Why Love Matters for Justice in which she describes how the duet offers 'a kind of internal freedom, a freedom of the spirit that consists precisely in not caring about hierarchy, neither seeking to avoid being controlled by others nor seeking to control them' (Nussbaum, 2013, p. 36). However, this essay focusses primarily on the 'nonmusical' diegetic sounds that are connected to the materiality of the space of the prison or the prisoner's own body.

2 Hunger's acute attention to framing and spectatorial positioning is strongly reminiscent of, and indebted to, Alan Clarke's Psy-Warriors (1981) and Elephant (1989). I am grateful to David Rolinson for drawing my attention to this important connection. See Rolinson (2005) and (2014).

3 See Brooks (2001) for an interesting discussion of the sound of breathing in the prison film Le Trou. 